\title{
Mobile Union Citizens Should Have Portable Voting Rights Within the EU
}

\author{
Roxana Barbulescu
}

The contributions to this forum have mixed two arguments that share some common concerns but do not fully overlap. The first one has to do with Union citizenship and its associated rights, the role of Union citizens for the political project of the European Union and the boundaries of a 'Eurodemos'. It is therefore, broadly speaking, an argument about the status of Union citizenship and a particular group of people: the nationals of other EU member states.

The second argument is more encompassing and concerns non-citizens who otherwise obey laws and pay taxes but have no voting rights. One way to enfranchise these people is for member states and the EU to grant residents voting rights and this is what the European Citizenship Initiative 'Let me vote' proposes. The other way to achieve this result is by naturalisation an option for which Rainer Bauböck, David Owen and Kees Groenendijk have argued convincingly. It is important to point out that naturalisation is an individual method of enfranchisement not a collective one. What both these methods seek to accomplish is to transform these persons from subjects into active citizens and thus to redress what Owen calls the democratic wrong. In other words, this argument is primarily about democratic deficit and the tensions and ills it causes in liberal democracies where not all their people have the right to vote.

This is a general argument and it applies not only to Union citizens but to all disenfranchised persons including non-EU migrants. Furthermore, this argument applies not only to EU member states but to all liberal democracies. If political rights need to be extended in order to fix the democratic deficit, then all residents and not only Union citizens should acquire these rights. But doing so one has to be aware that, as Dimitry Kochenov warns, that this exercise would only lead to another problem: the 'who are the people' question.

The matter at hands is, however, not about the general democratic deficit in societies of immigration, but about European integration and the pivotal role Union citizenship plays for the European Union project. I propose therefore an argument for portable political rights for mobile Union citizens. 


\section{Political rights for mobile Union citizens}

Compared with their fellow citizens, mobile Union citizens lose their political rights in the home country and most of the times they do not regain them at destination. This situation produces a cleavage between the mobile and the stationary Union citizens in the member state of origin as well as in the member state of residence. In this context, mobile Union citizens have only limited voting rights at the local level and in elections for the European Parliament while stationary Union citizens enjoy full political rights.

So far my argument is in line with Bauböck's: mobile Union citizens should not be penalised for exercising free movement right. However, we differ on the solution: voting rights in national elections should be portable across the EU and linked with (legal) residence. This mechanism is not new. It has guided the implementation of the EU rights Union citizens enjoy today: social contributions and pensions, medical insurance, local voting rights, etc.

In this scenario, Union citizens would be the ones deciding where they want to exercise their voting rights. They could register their residence in the destination country and transfer these rights there or they could 'hide' their change of residency from their country of origin and continue to enjoy political rights there. Sociological studies on the lifestyle of mobile Union citizens show that they skilfully combine rights they have 'at home' with rights they have in their new homes. Where Union citizens would choose to vote if they had the opportunity to do it either in their country of origin or of residence remains an open question and for most people, social ties and political loyalties will change with the passing of time.

\section{Why naturalisation solves too little too late}

When foreigners naturalise, they become citizens with full citizenship rights. They gain not only political rights but also access to a set of privileges reserved to nationals. The most common reserved privileges are public sector employment, service in the army, access to non-contributory social benefits and, of course, the right to vote in national election. It seems that a naturalisation option might actually solve the problem of disenfranchisement. And, it would do so not only for mobile Union citizens but also for their children and children's children. Why then is naturalisation not the most appropriate solution for Union citizens?

First of all, changing the rules of acquisition of their citizenship in 27 countries in order to make it easier for Union citizens to naturalise will take 
a lot of time. And, second, even if this happens nationality policies alone would not enfranchise Union citizens with political rights. At best, it would bring stronger incentives for this group of people to acquire citizenship and, with it, voting rights.

What this means is that the democratic deficit would persist until all Union citizens naturalise. This process might again take many decades because the decision to naturalise is ultimately an individual and personal one. Furthermore, judging from the low naturalisation rate amongst Union citizens, this moment might not arrive ever for the first generation of Union citizens.

A common EU directive granting Union citizens such rights directly achieves more and faster than naturalisation. Once implemented, this directive would automatically and simultaneously enfranchise all Union citizens.

Secondly, most contributions in this forum have presented enfranchisement by naturalisation and by voting rights as mutually exclusive alternatives. In fact, the two options tend to go hand in hand with each other. For instance, those member states that have a more open access to citizenship also give long-term residents the right to vote in local elections (the Scandinavian countries and the Netherlands as opposed to Spain, Italy, Greece and most new EU member states).

Thirdly, given that these are Union citizens we are talking about, it seems to me disproportionate to ask them to naturalise, and often also to renounce their original citizenship, in order to gain political rights. It is disproportionate for non-EU migrants but even more so for Union citizens.

Why that? Is there anything special about Union citizens who live in the European Union? Are they different from other foreign nationals living in a country other than their own somewhere else on the globe? I believe the answer to this question is yes. Member states and their citizens are partners in a shared European project with a common market, common economy and freedom of movement. Because of the specificity of the situation, alternative ways of political inclusion are preferable to naturalisation.

In addition, supporters of enfranchisement through naturalisation should also consider that by becoming a citizen in the country of residence a naturalised Union citizen would lose some of the substantive EU rights which she would otherwise enjoy as a Union citizen who resides in another member state. A naturalised Union citizen would thus be less a Union citizen than a new national citizen. 


\section{Political rights for Union citizens reloaded?}

Since political rights at the local level have already been agreed upon and implemented by the member states (many of which had to change their constitutions to allow non-nationals to vote or stand for office) then why is there still a debate on whether or not to enfranchise Union citizens?

Dora Kostakopoulou rightly point out in her contribution that many of the arguments made in this forum had been put forward when these rights were first introduced only two decades ago. This is a road we have walked before. This time, however, it is not a matter of starting afresh but rather a matter of extending the existing political rights to national elections.

If the European Citizens Initiative 'Let me vote' proves successful, it would do much good for the development and understanding of Union citizenship. Critics have long argued and for good reasons that this form of citizenship is little more than a legal status that developed in a piecemeal fashion largely through decisions the Court of Justice of the European Union. Nonetheless, a success of the ECI would demonstrate that there are real people, with names and surnames, who support it and claim more rights.

In conclusion, the main question this forum has asked is whether Union citizens should gain voting rights in national elections. While there is some disagreement on the method by which they should achieve these rights - via naturalisation or direct enfranchisement - it is important to highlight that all contributors have argued in favour of full political enfranchisement of Union citizens. None of the contributions considers satisfactory the status quo which limits the voting rights Union citizens have to local and EP elections.

Open Access This chapter is licensed under the terms of the Creative Commons Attribution 4.0 International License (http://creativecommons.org/licenses/by/4.0/), which permits use, sharing, adaptation, distribution and reproduction in any medium or format, as long as you give appropriate credit to the original author(s) and the source, provide a link to the Creative Commons license and indicate if changes were made.

The images or other third party material in this chapter are included in the chapter's Creative Commons license, unless indicated otherwise in a credit line to the material. If material is not included in the chapter's Creative Commons license and your intended use is not permitted by statutory regulation or exceeds the permitted use, you will need to obtain permission directly from the copyright holder. 